ISSN 2073-4441

www.mdpi.com/journal/water

Article

\title{
The Role of Geohydrology in the Determination of a Spatial Development Framework in the Vredefort Dome World Heritage Site
}

\section{Izak J. van der Walt ${ }^{1, *}$, Stephanus J. Pretorius ${ }^{2}$ and Carel B. Schoeman ${ }^{3}$}

1 Geography and Environmental Management, North-West University, Potchefstroom, 2520, South Africa

2 Africa Geo-Environmental Services, 76 Steve Biko Ave, Potchefstroom, 2531, South Africa; E-Mail: spretorius@ages-group.com

3 Town and Regional Planning, North-West University, Potchefstroom, 2520, South Africa; E-Mail: calie.schoeman@nwu.ac.za

* Author to whom correspondence should be addressed; E-Mail: Kobus.vanderwalt@nwu.ac.za; Tel.: +27-182-991-584; Fax: +27-182-991-580.

Received: 3 September 2010; in revised form: 28 September 2010 / Accepted: 12 October 2010 / Published: 19 October 2010

\begin{abstract}
Surface water resources (the Vaal River and its tributaries) in the Vredefort Dome World Heritage Site (VDWHS), South Africa, have been over extended and future development will rely solely on groundwater. Hence, being at a critical point in the water balance, groundwater resources in the VDWHS require careful management and protection to ensure sustainability and equitable access. An assessment of the geohydrological character of the VDWHS was therefore done in order to develop a groundwater resource management plan. Five groundwater resource management units were delineated and resource measures for each management unit were developed based on physical and anthropogenic attributes. Due to the importance of groundwater in the VDWHS, it was determined that geohydrology should play a major role in the alignment of the environmental, spatial and statutory development frameworks, in order to ensure good governance. A geohydrological-based land use management guideline and spatial development framework was developed to optimize the integration between the water sector, the environmental sector and land use and spatial planning sector. It was concluded that a geohydrological assessment needs to form the basis of all future land use management and spatial planning activities in the VDWHS.
\end{abstract}


Keywords: geohydrology; Vredefort Dome; ground water management; land-use management; spatial planning

\section{Introduction}

The Vredefort Dome is the most clearly defined, largest and oldest meteorite impact structure on earth, and was listed in 2005 as a World Heritage Site to protect a portion of this astrobleme for future generations [1,2]. It currently still awaits formal proclamation by UNESCO. The delineated Vredefort Dome World Heritage Site (VDWHS) is situated approximately $100 \mathrm{~km}$ south west of Johannesburg, South Africa, and it covers approximately a quarter of the entire impact crater and related impacted geology-see Figure 1. The study area is mainly privately owned and water uses are related to basic human needs, agricultural practices and, to a lesser extent, tourism activities. Although the region is drained by the perennial Vaal River which flows from east to west through the southern and central portions of the study area, most activities in the VDWHS rely exclusively on groundwater resources for the provision of water due to the mainly rural setting as well as the fact that the Vaal River has been over extended by industrial and mining activities upstream of the VDWHS [3]. In a strategic environmental assessment of the area, it was concluded that no regional geohydrological assessment was available to develop a geohydrological management plan for the VDWHS [3]. Such an assessment would have to take cognizance of the regional geological setting and the existing institutional developmental and environmental legal framework in South Africa [4]. As such, it is important to select an appropriate scientific methodology to achieve a sustainable balance between consumptive use and non-consumptive use [5]. Groundwater management objectives in South Africa have changed dramatically on a national level since the abolishment of the previous political dispensation and groundwater became a significant component of integrated water resource management as was foreseen in the National Water Act (Act 36 of 1998) [6]. This Act changed the status of groundwater from a private to a public resource, indicating a greater recognition of the importance and role of groundwater as a water resource [7,8].

The geohydrological assessment of the VDWHS was based on the groundwater character and potential of the study area, which depends on the interaction of the following factors [9]:

- The character of the geology and related groundwater aquifers: A higher groundwater potential is normally associated with fractured and non-homogeneous rocks, contact between two rock types of different competency associated with locally significant dykes and structural features.

- The availability of surface water and the potential recharge from surface water drainage: A higher groundwater potential is normally associated with areas where a higher level of interaction between surface water flow and aquifers occurs. However, virgin recharge as such is not the major factor in determining sustainability, but rather optimal yield. This is not a fixed value, but varies according to a range of given situations, necessitating the need for adaptive management [8].

- The existing groundwater practices and land uses within the area. 
Figure 1. The Vredefort Dome World Heritage Site: Local setting (a), its locality within South Africa (b) and the impacted geology (c) (Note - the three images in Figure 1 are for orientation purposes only. For a detailed geological map, refer to Figure 2).
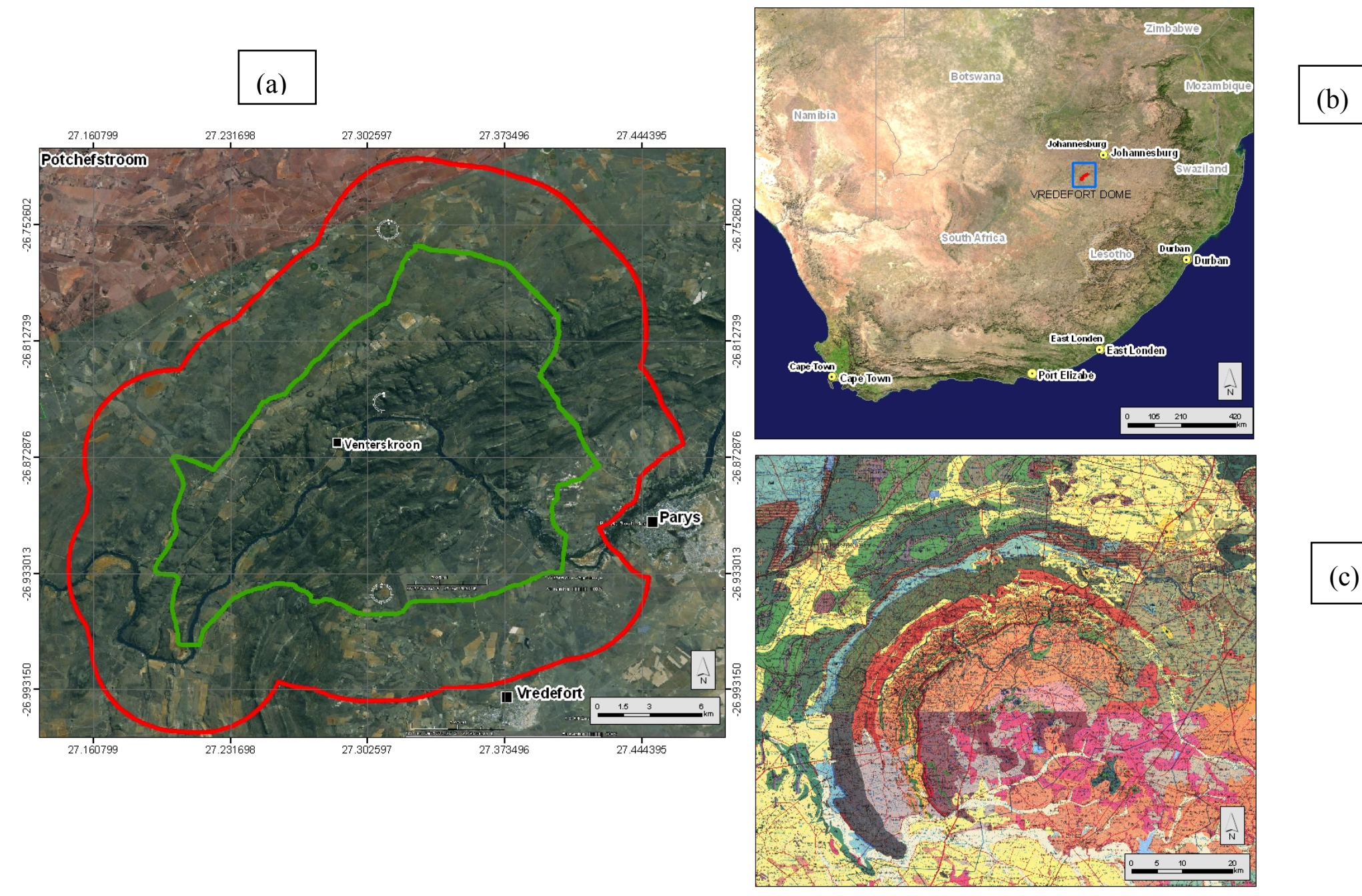

(c) 


\section{Research Method}

A geohydrological investigation was conducted in order to investigate the existing groundwater use, groundwater quality and groundwater properties within the VDWHS. A literature review on delineation of groundwater management units, the results from the groundwater geohydrological investigation as well as regional geological, geomorphological and geohydrological information augmented by aerial photograph interpretations was used to delineate the different groundwater resource management units in the VDWHS.

\subsection{Basis of Delineation}

Groundwater resource units form the basis of spatial ordering and groundwater resource maps [10]. Information regarding geological formation character, lithology, stratigraphy, physiographic aspects, structural geology, surface water features, surface and groundwater interaction, recharge as well as geohydrological parameters is necessary to delineate groundwater resource management units [11-18]. To ensure sustainability, aspects of both the natural and the social environment have to be integrated into the development of a groundwater management plan for the VDWHS [1]. The following natural and social aspects were therefore used to delineate and define five groundwater resource management units in the VDWHS:

- Geological and structural geological setting: Specific aquifer systems acting as one resource and manageable unit are defined by the geological formations and their physical character reflecting depth and character of weathering.

- Geomorphological setting: Specific aquifer systems are defined by river valley development and hill formation throughout the VDWHS area.

- Aquifer characteristics as reflected by geohydrological parameters (water level from surface, water chemistry, and yield), and;

- Institutional reality and social structuring: This includes the borders of the VDWHS, and existing and expected development zones.

Based on the indicated aspects, a geohydrological assessment (recharge determination, water balance, flow direction, water quality and risk assessment) was done for each groundwater resource management unit. The results of these assessments were used to develop procedures to manage, protect and monitor each groundwater resource management unit. The influence of the aquifer characteristics within the different groundwater resource management areas on the land-use and spatial development framework in the VDWHS was defined, after which spatial planning and land-use management guidelines and procedures based on the integration of land-use management with geohydrological attributes were developed. Finally, a methodology regarding geohydrological assessments required in order to support land-use applications and future spatial planning within the VDWHS was proposed. It should be noted that the main aim of this paper is not to describe the surface water-groundwater interactions in detail, but to highlight the unavailability of surface water for any future developments and the resultant complete dependence on ground water in the VDWHS, to propose sustainable management strategies to protect this valuable groundwater resource, and to caution against the possible ingress of (polluted) water from the Vaal River in case of over-abstraction from certain 
vulnerable aquifers in the VDWHS.

\subsection{Geological Setting}

Geology forms the basis for the existence of the Vredefort Dome as a World Heritage Site, reflecting the oldest and largest visible impact structure known to man [19].

A detailed geological description reflecting the complex unique geological setting of the Vredefort Dome and the formation model as a crater impact site have been described in detail [19-22]. A comprehensive reference list regarding literature pertaining to the Vredefort Structure and related geological and physical aspects and reflecting the vast existing knowledge regarding the geological setting of the study area is given by Reimold and Coney [23]. Details regarding the proposed management of this important geological setting and the related heritage value are addressed in the Geological Management Plan in the Integrated Management Plan (IMP) of the VDWHS [4].

The main structures were obtained from a map entitled "The geology of the Vredefort Dome" [20] and are presented in Figure 2. In addition, structural geological information obtained from aerial photograph interpretation [24] was used to identify widespread younger faults and joints developed as linear structures in the study area (Figure 3). Two dominant joint sets were identified, one orientated in a north-south direction, the second in a northwest-southeast direction as displayed in the structural compilation.

\subsection{Land Use}

The following generalized land use zones have been identified during the SEA study [3]:

- Mixed farming occurs where crop production is practiced commercially or to support the fodder flow of livestock. Small portions of land are planted under irrigation for winter grazing.

- Livestock farming occurs with the primary use of extensive animal production where fodder is provided during the harsh winter months.

- The combination conservation/livestock farming occurs in the central area of the VDWHS with a low grazing capacity and moderate to high browsing capacity. Conservation and game farming, integrated with livestock and tourism, are the preferred land uses. Two zones with a focus on either conservation or livestock are indicated in Figure 4.

Irrigation farming occurs on the flood plains of the Vaal River with approximately 450 ha with right of irrigation. 
Figure 2. Geology of the VDWHS.

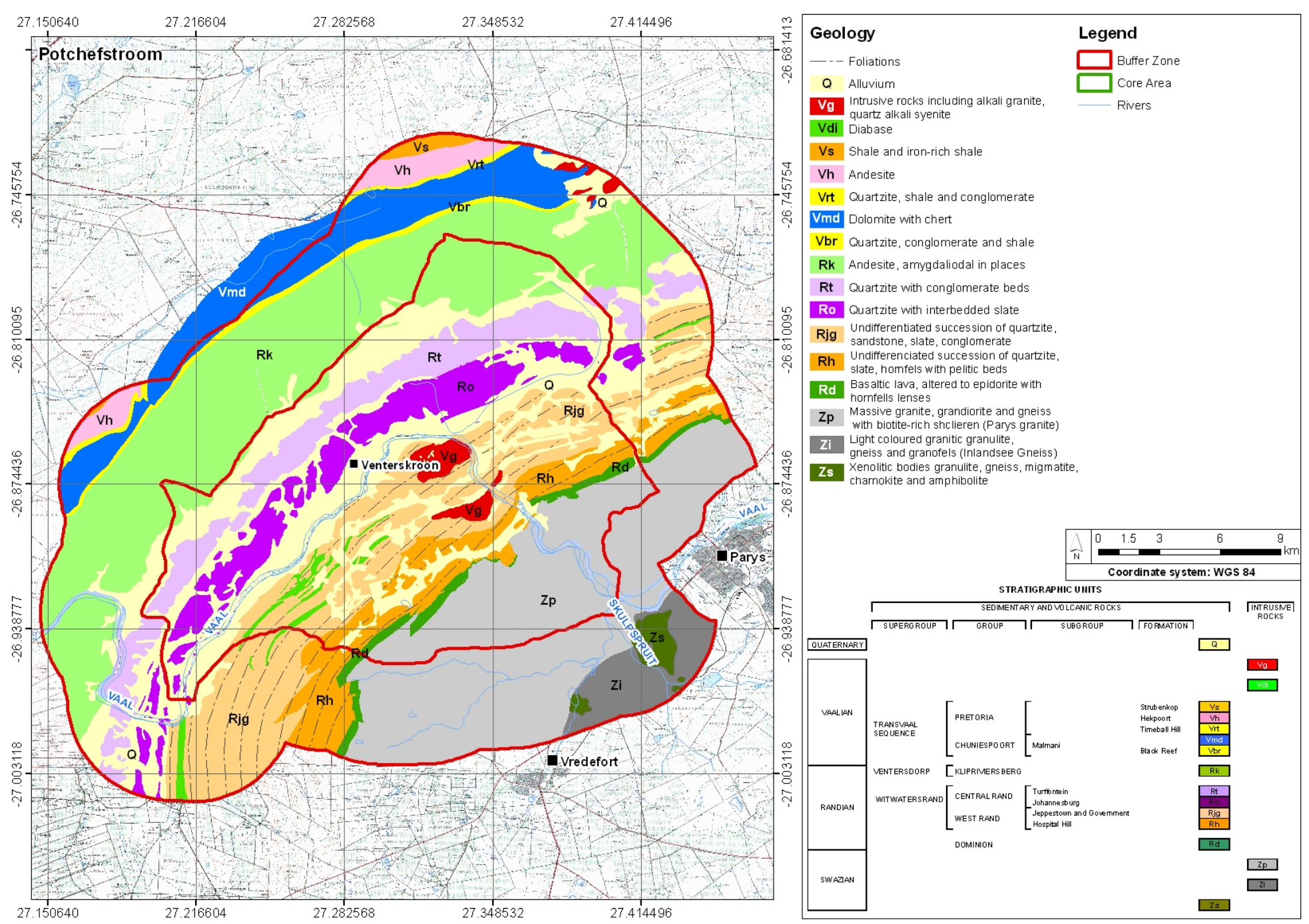


Figure 3. Faults and joints within the VDWHS.

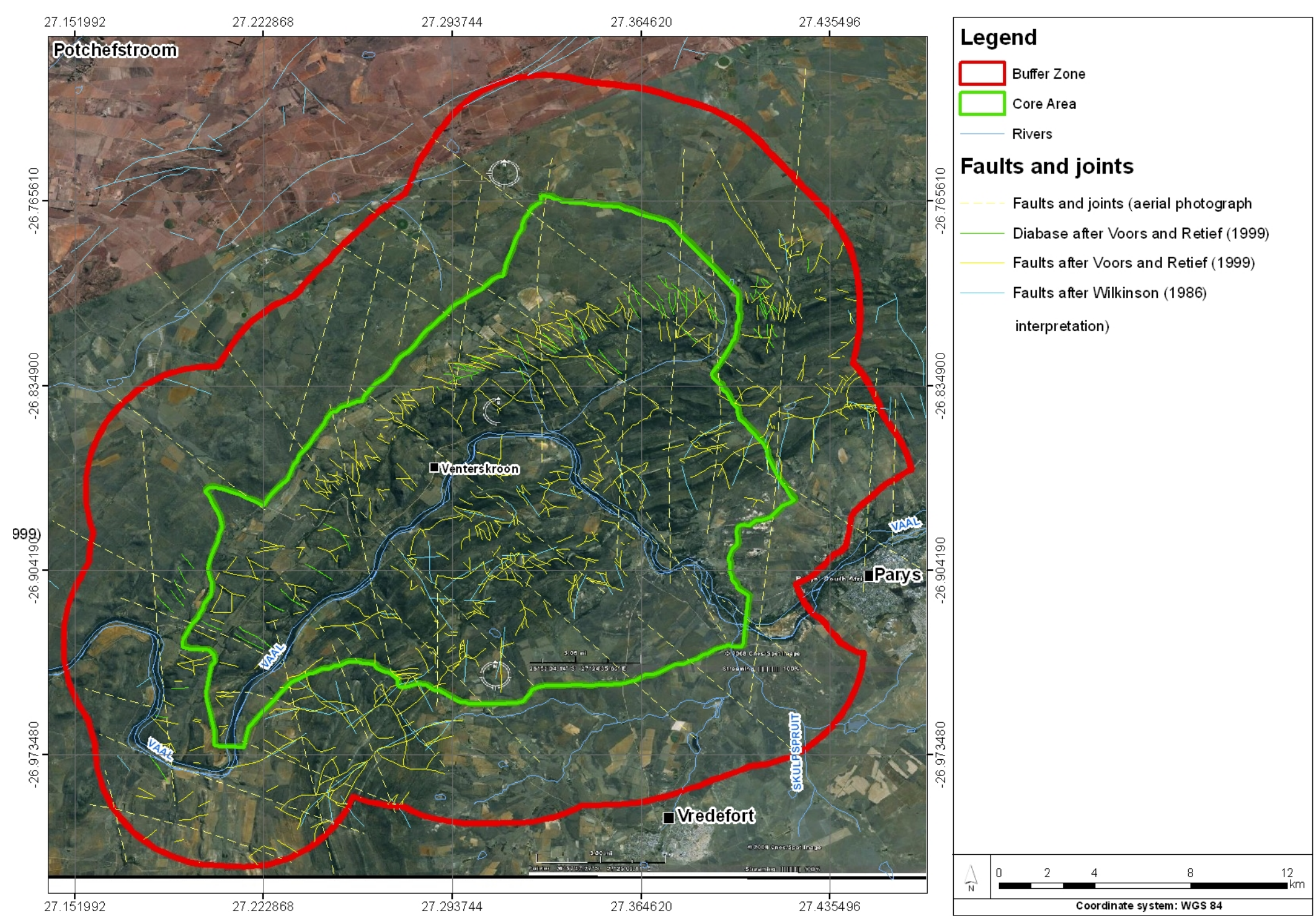


Figure 4. Land-use zones within the VDWHS.

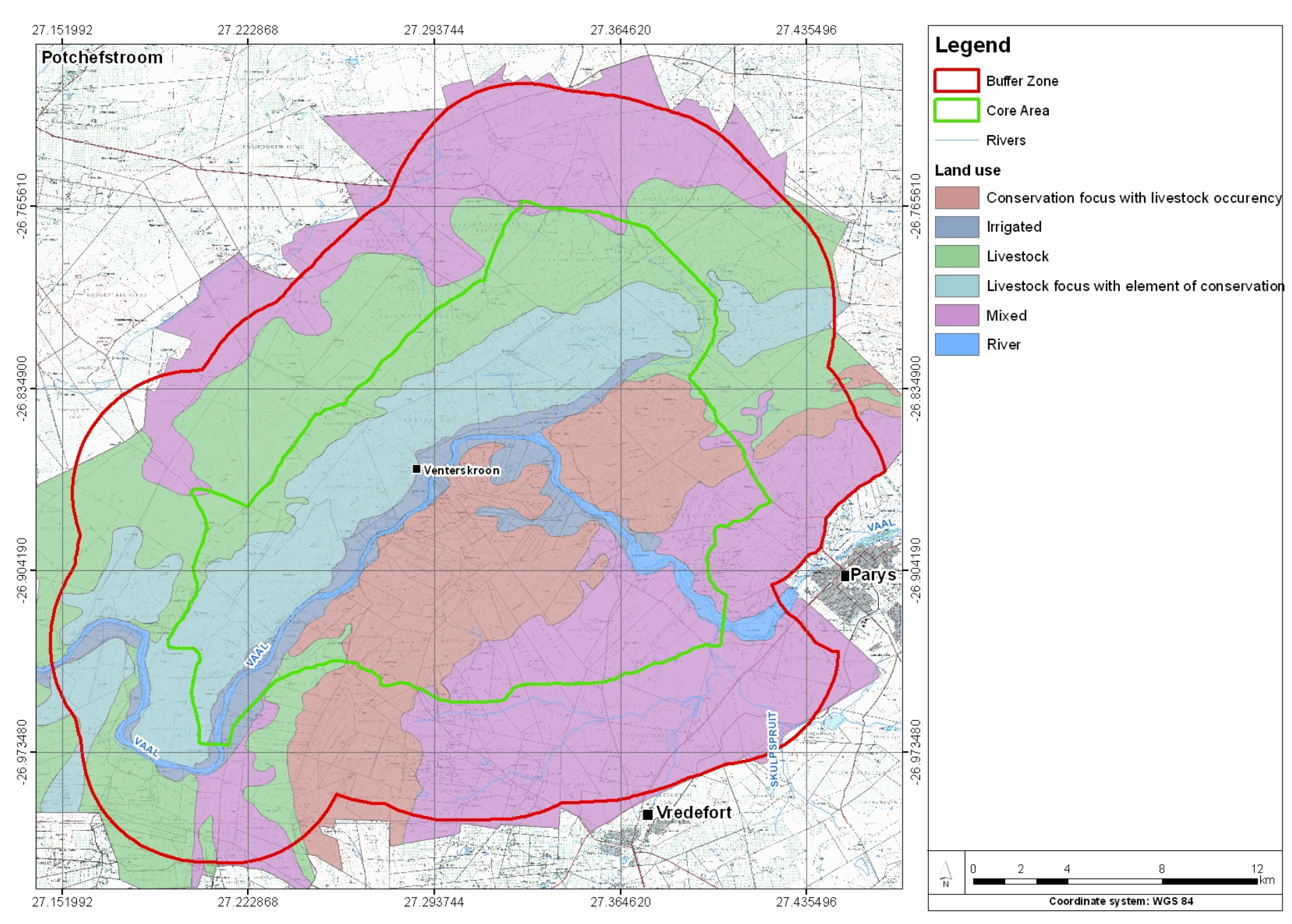




\subsection{Geohydrological Status Assessment}

On the 1:500,000 general geohydrological map series, Johannesburg 2526 [15], different geohydrological units were defined for the regional area based on lithology, stratigraphy and the character of the related geological formations. Although generalized, it illustrates the application of the same principles that were used in the delineation of different groundwater zones in this study. According to the evaluation by the Groundwater Resource Directed Measures software application, the study area, which is mainly an intergranular and fractured rock type aquifer, shows a borehole yield median of between 0.5 and $21 / \mathrm{s}$ [26].

The physical parameters of the different rock types in the study area play a major role in the geohydrological assessment and are used spatially to define and present the groundwater potential and aquifer character of the VDWHS. Different stratigraphic units and related groundwater potential areas form mainly northeast-southwest elongated trending zones with difference in local groundwater potential.

\section{Results}

\subsection{Groundwater Potential Zones}

Five groundwater potential zones for the VDWHS were identified and delineated and are shown in Figure 5. A brief description of each zone follows.

- Zone 1: Granite, gneiss and intrusive rocks exhibit a low groundwater potential with a recharge probability of 3-4\% of mean annual precipitation (MAP) [34]. Local variation in texture occurs in the granites and gneisses of the hub of the VDWHS [20], giving rise to a variation in weathering. In combination with faults and dykes and the availability of surface water infiltration in drainage systems, specific zones within the granite present the possibility of borehole development.

- Zone 2: Quartzite dominated successions giving rise to the development of prominent hills throughout the study area and a low groundwater potential occur due to the near-surface bedrock [27]. A recharge probability of between 3-4\% of the MAP is reported for quartzites from the Witwatersrand Supergroup [26]. Local linear aquifer development is typical of the quarts dominated successions associated with cracks and fissure zones along dykes, faults and shear zones [27]. A combination of the presence of an intergranular aquifer in overlaying alluvium and the availability of surface water infiltration, can give rise to localized higher potential zones in these areas.

- Zone 3: Lavas and basalts have a low groundwater potential with a recharge probability of $4 \%$ of the MAP [26]. Areas underlain by massive occurrence of shale in groups within this category indicate a very low recharge probability of $2 \%$ of the MAP [26].

- Zone 4: Alluvium and unconsolidated material and deeply weathered material typically associated with the surface drainage systems are considered areas of moderate groundwater potential. The deeper weathering increases not only the transmissivity, but also the storativity of the matrix, giving rise to the development of main aquifers in the valley fills. Although higher groundwater is expected in these areas, it is highly dependent on recharge and vulnerable to artificial change in balance [26]. Although the boreholes developed within the alluvium can be high yielding, they may have a lower sustainable yield since they are dependent on the rainfall, which is seasonal by nature. 
- Zone 5: Dolomites from the Malmani subgroup have a moderate to high groundwater potential with a recharge potential of $6 \%$ of the MAP [26]. A local variation in weathering occurs in these rock types with chert and chert-breccia forming more weather-resistant zones [20]. Groundwater is stored and transmitted through cavities and fractures in the carbonate rock giving rise to a complex interaction of groundwater throughout the succession. From the complex structural geological character [27], it is evident that a complex network of faults, cracks and fissures along dykes and shear zones exist in the study area. This network gives rise to the development of linear secondary aquifers that may serve as conduits resulting in groundwater transfer from one to another catchment area and lithological unit. This geological character will give rise to a complex groundwater flow pattern which will significantly influence the geohydrological follow-up work and modeling.

\subsection{Geohydrological Investigation}

A geohydrological investigation was conducted over an area of almost $350 \mathrm{~km}^{2}$ at 460 sites, of which 18 were identified as natural springs and the rest existing boreholes. The position and status of the boreholes are shown in Figure 6. Water of 138 boreholes were chemically analyzed and classed for human consumption.

The geohydrological investigation recorded information on borehole condition, equipment, status, and location. Abstraction rates and information pertaining to supply reliability were not measured but were derived from the equipment/infrastructure survey and usage information. Where possible the water levels were also measured in the boreholes.

The following observations were made from the geohydrological investigation:

- Only 285 out of 460 surveyed boreholes and springs are operational (62\%), 161 are not currently in use (35\%) and 14 boreholes are deemed destroyed (3\%). Of the operational boreholes, $32 \%$ are used for domestic purposes, $31 \%$ for both domestic use and livestock, $18 \%$ for stock watering and only $5 \%$ each for irrigation and a combination of agricultural and domestic use.

- Eighteen springs were identified in the study area during the geohydrological investigation. Eleven of these springs are used for stock watering or irrigation purposes. Some are uncovered and in some instances contaminated by carcasses and cattle manure. The springs are mostly associated with localized perched aquifer conditions within quaternary alluvium formations overlying a known deeper secondary linear aquifer system. The sustainability of the springs in the alluvium is expected to be low and recharge dependent as the near-surface character of bedrocks give rise to a shortage of groundwater [27]. A number of springs occur in shallow alluvium overlaying massive andesitic lava to the north and granites to the south.

- The number of boreholes and springs recorded which are not in use amount to 161. The majority of these boreholes are not used because their water source has dried up or the boreholes have collapsed. Some of the boreholes were identified to have poor quality water and the users decided to drill elsewhere for an alternative supply.

- Fourteen (14) destroyed boreholes were identified. These boreholes cannot be rehabilitated due to obstruction and collapse. 
- The equipment of the boreholes is dominated by submersible pumps at 186 of the operational and equipped boreholes (65\%). Wind pumps were the next most frequent occurring with 47 out of 285 equipped boreholes in use $(16 \%)$ while positive replacement pumps were used in 25 cases $(9 \%)$ and power-heads and other equipment in 27 cases $(10 \%)$.

From the geohydrological investigation it is evident that domestic water supply as well as farming activities (small scale irrigation, livestock and small scale game watering) in the VDWHS is totally dependent on groundwater. This supports the classification of the aquifers as being a sole source under the system of Parsons [28].

\subsection{Water Levels and Flow Direction}

The depth to water table was measured during the geohydrological investigation at 205 boreholes, reflecting an average water level of $16.55 \mathrm{~m}$ below surface with a standard deviation of $11 \mathrm{~m}$ and a median value of $15.40 \mathrm{~m}$. In unconfined aquifers flowing under gravity, the water table is a subdued replica of the topography. This information regarding the static water level/piezometric head is an important component of the geohydrological conceptual model representing the natural system [29]. The mapping of the phreatic surface was done by applying Kriging [30]. From this, zones with the same expected water levels were identified and a map of the static water table was compiled in order to contribute to the understanding of the groundwater conceptual model of the study area (Figure 7).

The following conclusions were made from this information:

- Water levels follow a general northeast-southwest trend correlating with geological formations, giving rise to different zones in need for different management objectives.

- The Vaal River drainage system shows no effect on the groundwater level pattern. This indicates in general that recharge from surface water to groundwater from the Vaal River is restricted.

- The deepest water levels occur in the northwest of the VDWHS in the area underlain by andesite as part of the Ventersdorp Supergroup. This is probably caused by the low groundwater potential related to lavas and basalts and is indicative of the effect of local groundwater abstraction from the related aquifer with lower permeability and transmissivity. The authorization of any land use and groundwater related use activity in this area should therefore be based on a detailed geohydrological assessment of the area.

- The shallow water levels (2 to 4 meters) near the towns of Parys and Vredefort indicate that the groundwater aquifers in these areas are highly vulnerable to pollution and surface related activities. Any activities with a negative environmental impact like poorly designed and managed sewerage systems can have a severe influence on water quality and should be monitored and managed accordingly. 
Figure 5. Groundwater potential zones in the VDWHS.

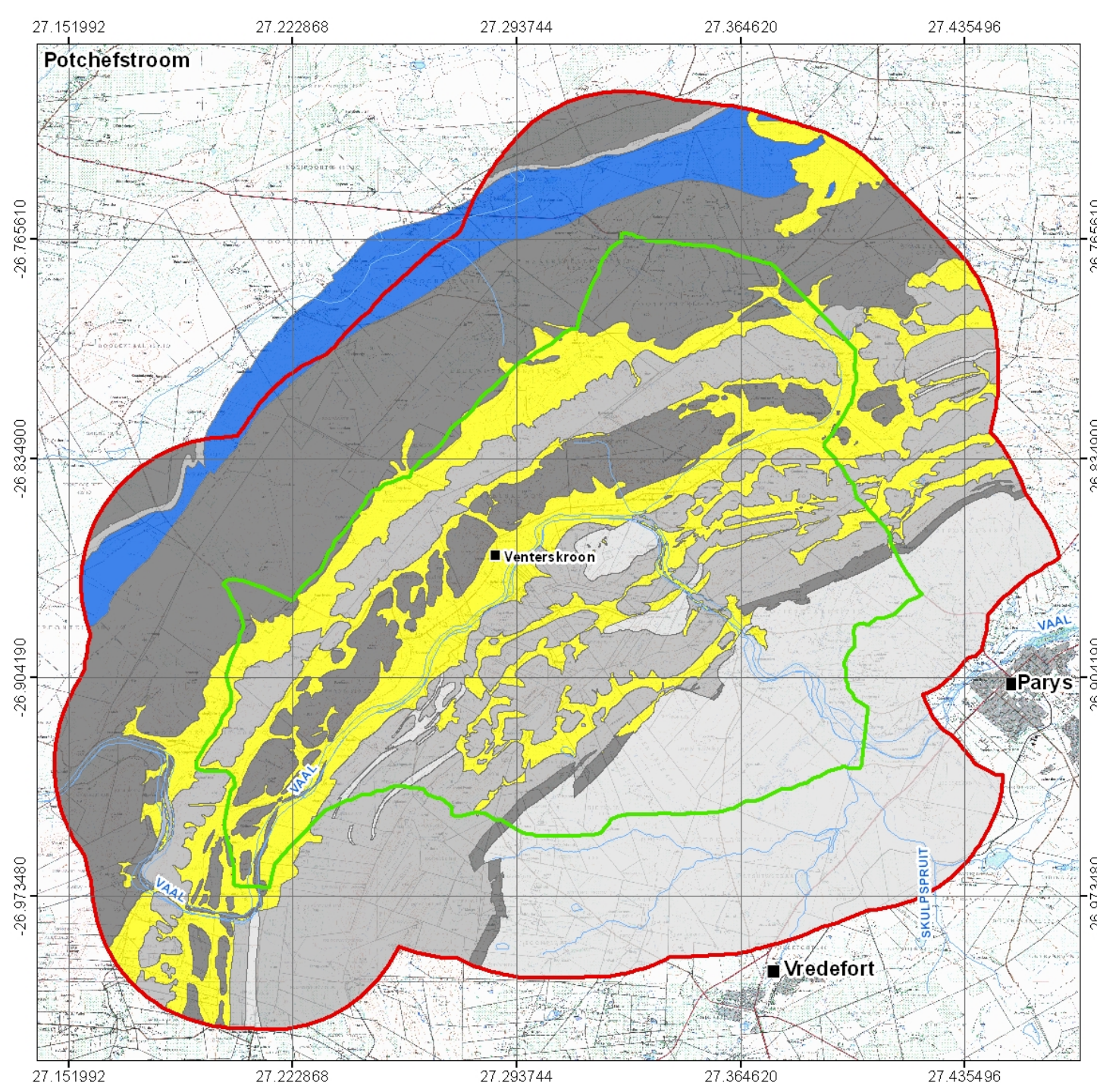

\section{Legend \\ $\square$ Buffer Zone \\ Rivers}

Groundwater potential

$\square$ Low: Granite-Gneiss and intrusive rocks
Low: Quartzite dominant successions

Low: Lavas, basalt and shales

Moderate: Alluvium

High: Dolomite

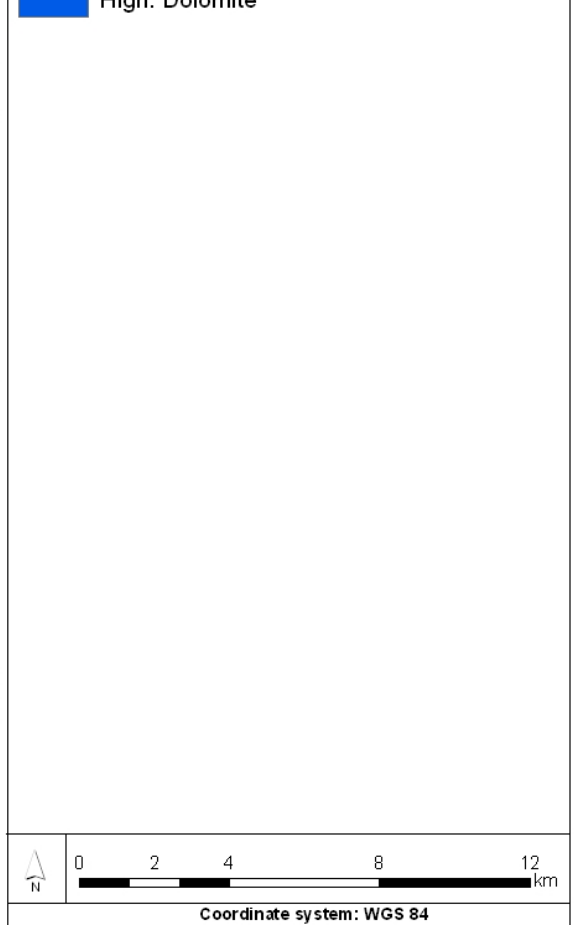


Figure 6. Borehole status in the VDWHS.

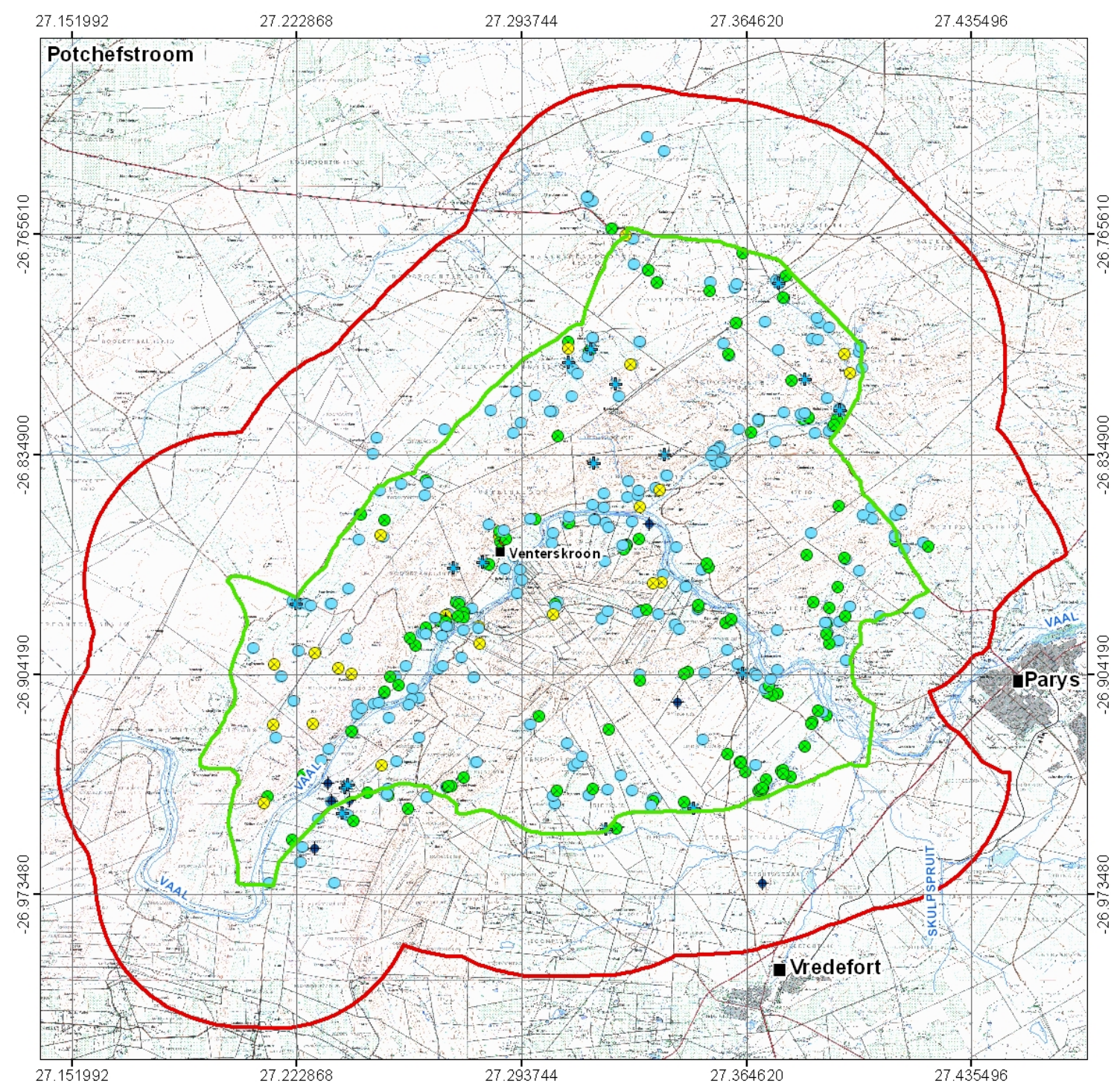

Legend

$\square$ Buffer Zone

Core Ar

Groundwater potential

* Spring

- Destroyed

- Dewatering, destroyed

- Water supply, destroyed

Q Unused

- Water supply, unused

- Water supply, in use

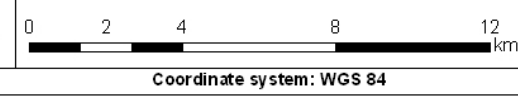


Figure 7. Depth to water table in the VDWHS.

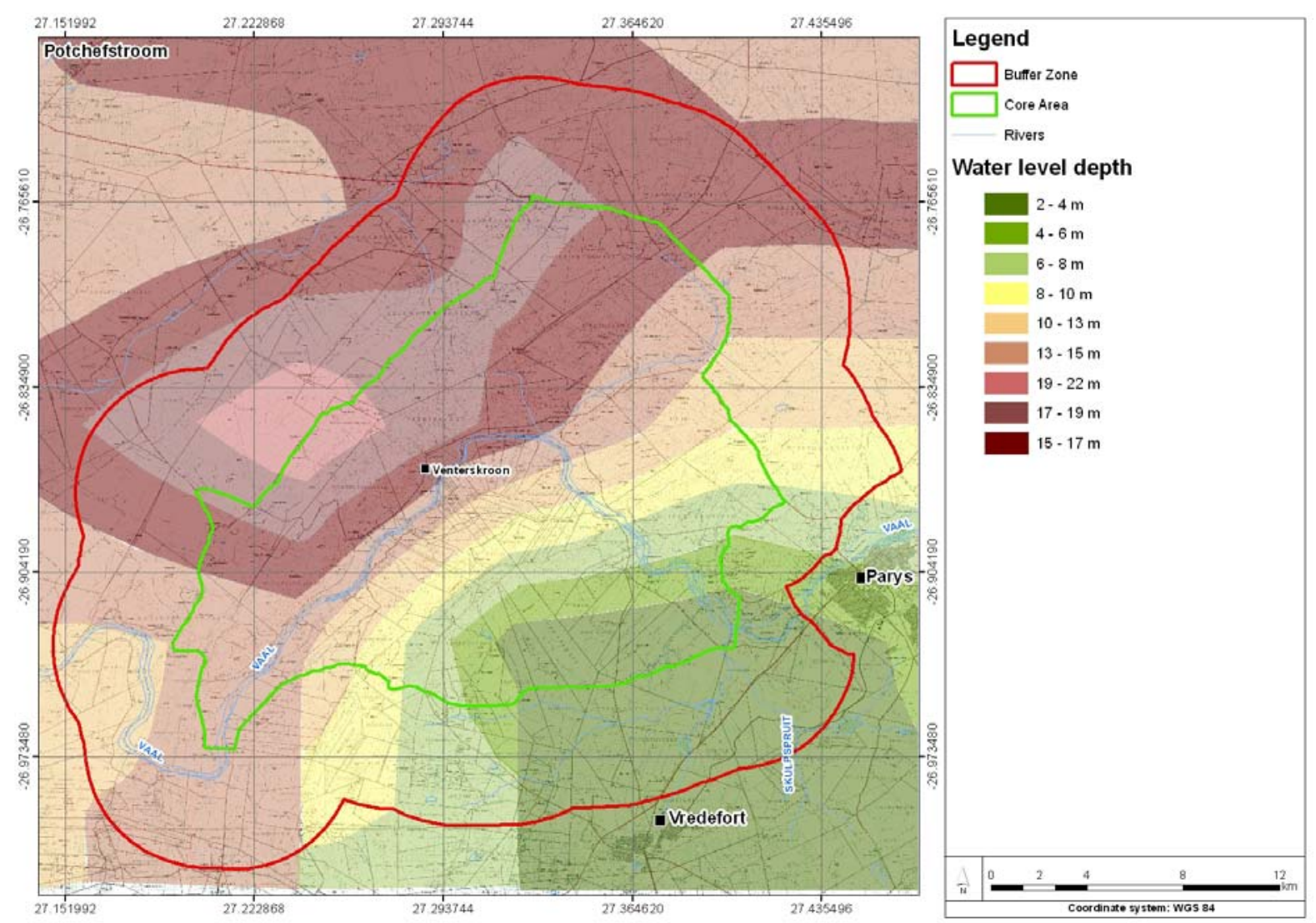

A grid-based graphic surfer model program [3], as well as Kriging [30], were used to interpolate irregular spaced XYZ data into a regular space grid. The grid was then used to produce measured flow directions and measured heads (Figure 8 ). The following conclusions could be made:

- Water abstraction from boreholes gives rise to local dewatering as an indication of the low critical balance in water demand and availability.

- Variation in flow directions is indicative of the effect of structural geology on the flow of groundwater within secondary linear aquifers throughout the study area.

- Groundwater flow follows the surface water flow direction with flow towards the Vaal River and tributaries in general. It is therefore apparent that the Vaal River is acting as an output for the underlying aquifers within the central and southeastern sections of the VDWHS.

- The groundwater flow moves against the flow of the Vaal River in the western parts of the VDWHS in the area underlain by lavas, basalts and shales. This indicates that the river may be acting as a local input, or may be entirely disconnected from the aquifer.

- Groundwater flow crosses geological strata and confirms the existence of linear aquifers in the study area as described by Brink [27].

- Abstraction from boreholes gives rise to local dewatering and indicates the sensitive water balance in the study area.

- The groundwater flow patterns indicate that pollution of shallow aquifers within the VDWHS may contribute to the surface water pollution in the Vaal River. Additionally, a decrease in base flow with additional groundwater abstraction is likely. 
Figure 8. Groundwater flow directions in the VDWHS.

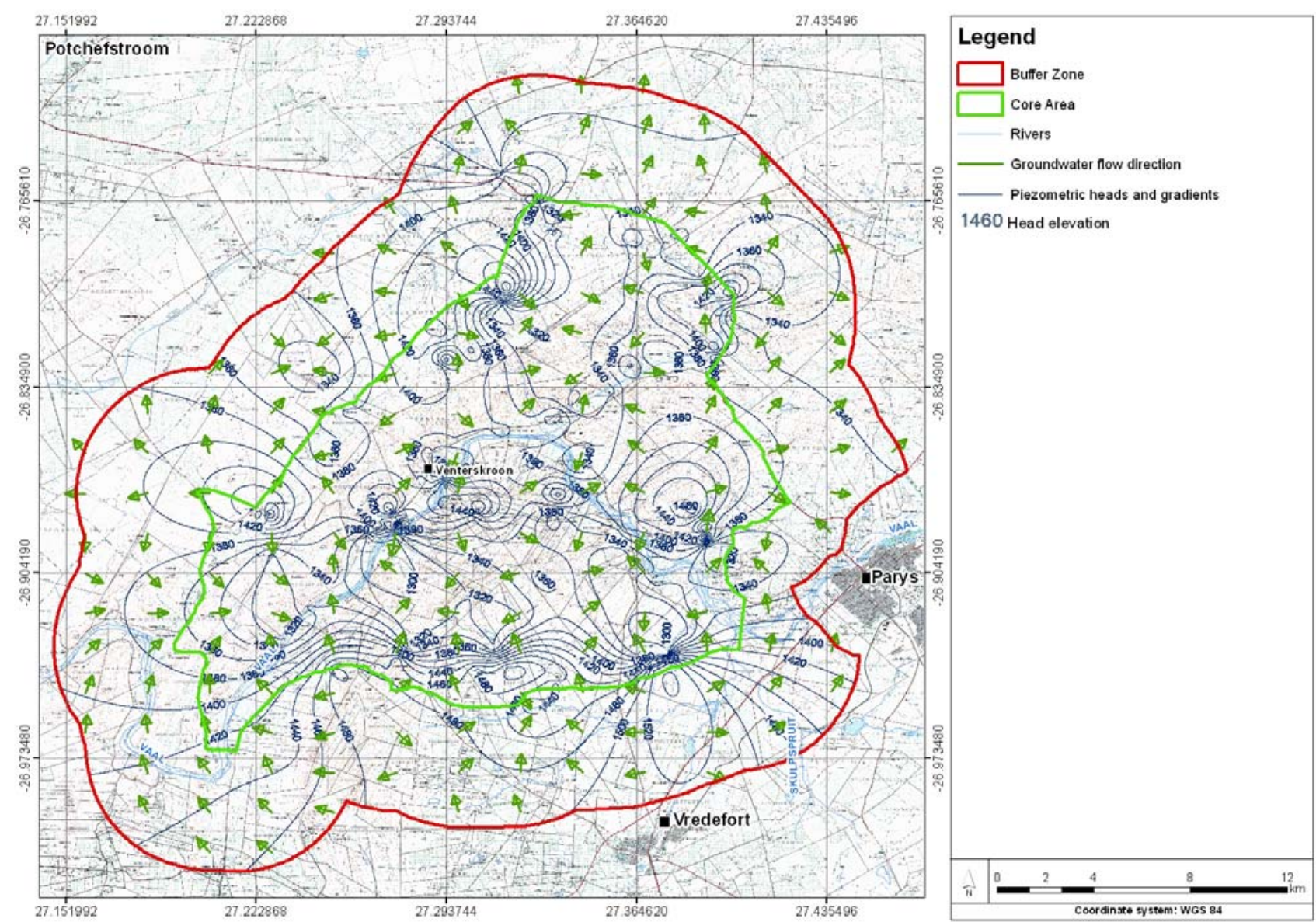

\subsection{Water Quality}

Sampling of boreholes was done according to the sampling guide [32]. The samples were analyzed for macro- and micro-elements including fluoride, electrical conductivity and $\mathrm{pH}$. The results were compared to the South African Department of Water Affairs and Forestry Drinking Water Guidelines [33], the quality assessment guide [34], as well as to the South African National Standard for drinking water quality SABS 241 [35]. Irrigation standards were used for indicative purposes [36], see Table 1. The spatial water quality distribution according to the National Standard for drinking water quality [35] is shown in Figure 9. 
Table 1. Summary of the water quality and comparison with standards.

\begin{tabular}{|c|c|c|c|c|c|c|c|}
\hline \multirow[t]{2}{*}{ Element } & \multirow[t]{2}{*}{ Minimum } & \multirow[t]{2}{*}{ Maximum } & \multirow[t]{2}{*}{ Mean } & \multirow{2}{*}{$\begin{array}{l}\text { Standard } \\
\text { deviation }\end{array}$} & \multicolumn{3}{|c|}{ Allowable limits } \\
\hline & & & & & $\begin{array}{c}\text { Human } \\
\text { consumption } \\
(\mathrm{mg} / \mathrm{L}) \\
\end{array}$ & $\begin{array}{c}\text { Animal } \\
\text { consumption } \\
(\mathrm{mg} / \mathrm{L})\end{array}$ & $\begin{array}{c}\text { Irrigation } \\
\text { (mg/L) }\end{array}$ \\
\hline $\mathrm{Ca}$ & 5 & 155.5 & 25.2 & 23 & 150 & 1,000 & - \\
\hline $\mathrm{Mg}$ & 0.49 & 102 & 18 & 20.3 & 70 & 500 & - \\
\hline $\mathrm{K}$ & 0 & 26.2 & 2.42 & 3.9 & 50 & - & - \\
\hline $\mathrm{Na}$ & 0 & 235.6 & 23.5 & 28.5 & 200 & 2,000 & - \\
\hline $\mathrm{SO}_{4}$ & 0.69 & 514.7 & 29.1 & 64.9 & 400 & 1,000 & - \\
\hline $\mathrm{NO}_{3}$ & 0.2 & 169.9 & 19.5 & 27.8 & 10 & 100 & 5 \\
\hline $\mathrm{NH}_{4}$ & 0.14 & 71.3 & 2.17 & 8.9 & 1 & - & - \\
\hline $\mathrm{Cl}$ & 0.71 & 433.9 & 24.4 & 48.1 & 200 & 1,500 & 100 \\
\hline $\mathrm{HCO}_{3}$ & 3.05 & 414.9 & 142.6 & 100.1 & - & - & - \\
\hline $\mathrm{pH}$ & 5.49 & 8.35 & 7.16 & 0.57 & $5.0-9.5$ & - & $6.5-8.4$ \\
\hline $\begin{array}{c}\mathrm{EC} \\
(\mathrm{mS} / \mathrm{m})\end{array}$ & 2 & 276 & 39.5 & 36.5 & 150 & - & - \\
\hline TDS & 13 & 1794 & 257.1 & 237.3 & 450 & 1,000 & 40 \\
\hline $\mathrm{F}$ & 0 & 5 & 0.07 & 0.51 & 1 & 2 & $2-15$ \\
\hline $\mathrm{Mn}$ & 0 & 2.71 & 0.06 & 0.28 & 100 & 10 & $0.02-10$ \\
\hline
\end{tabular}

Figure 9. Groundwater quality in the VDWHS.

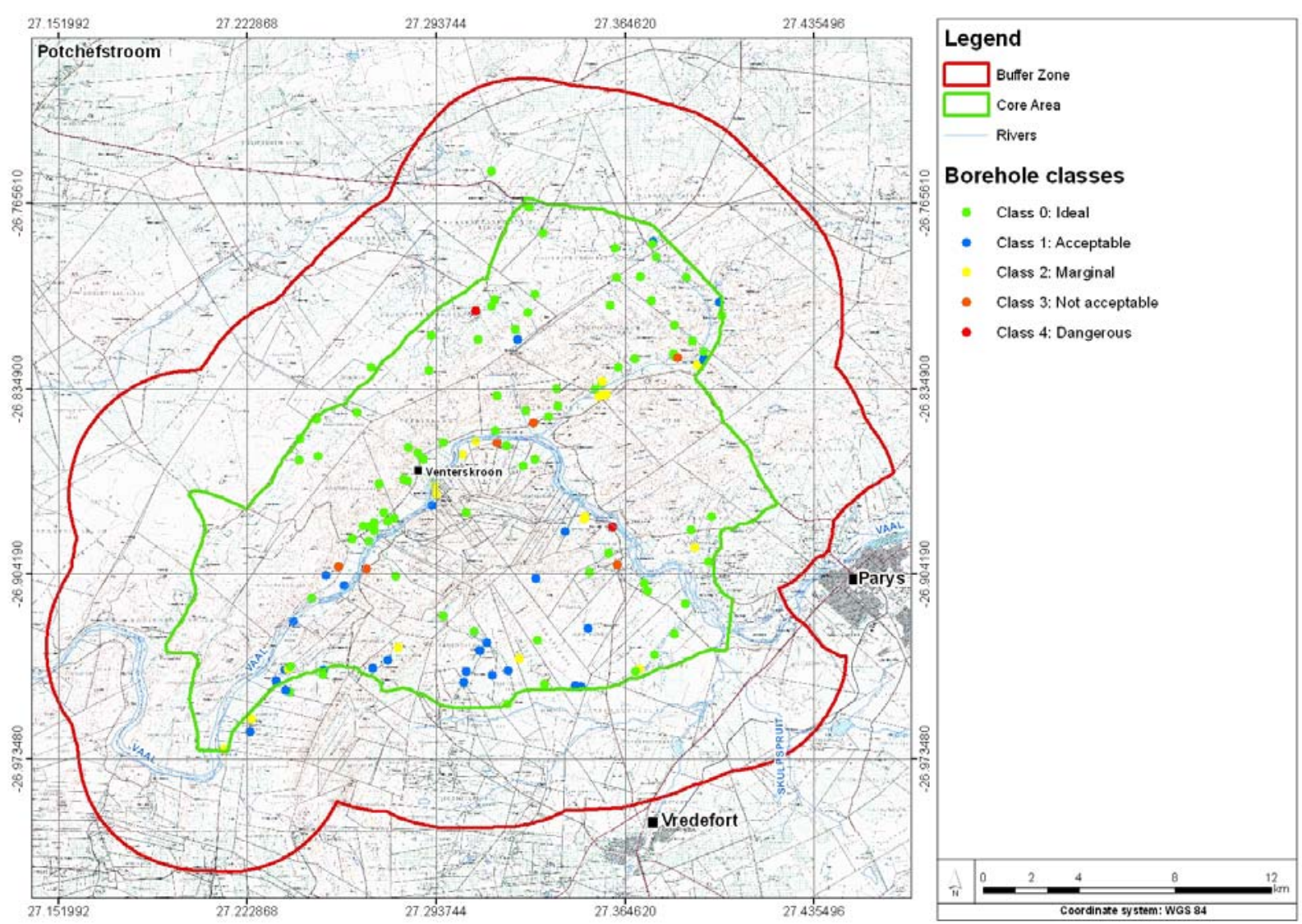


The water chemistry reflects the following aspects that must be taken into consideration in future effective management of groundwater in the VDWHS:

- The water quality in the majority of boreholes is acceptable with 84 out of 138 samples being classified as Class 0 or ideal against the drinking water standards. Added to this, another 28 samples were considered to be Class 1, which is also acceptable for drinking purposes under this standard. This means that $82 \%$ of the boreholes sampled have acceptable water quality.

- The $18 \%(\mathrm{n}=26)$ of the boreholes which are not considered as acceptable are indicative of local influences rather than a regional trend and need further investigation.

- A higher concentration of low quality groundwater (unsuitable for human consumption) is located within the Vaal River drainage system associated with shallow unconfined aquifers consisting of alluvium, sand, soil, gravel, and ferricrete with a high expected hydraulic conductivity. The water chemistry with typical nitrate of more than $50 \mathrm{mg} / \mathrm{L}$ and ammonia concentrations averaging $0.1 \mathrm{mg} / \mathrm{L}$ is indicative of pollution of groundwater from surface activities including decay of plant, animal and human waste. Direct causes may include high intensity land use activities such as poorly designed and managed septic tanks and/or high animal concentrations.

- The fluoride content of two of the samples are well above the recommended limit of $1.5 \mathrm{mg} / \mathrm{L}$ $(3,12$ and $5,15 \mathrm{mg} / \mathrm{L})$ and are currently used for domestic purposes. High fluorite content was also reported from boreholes $3 \mathrm{~km}$ to the northwest from the VDWHS [6]. Fluoride is mostly brought into groundwater by leaching from minerals in rocks but may also be affected by chemical fertilizers in agricultural areas [37].

- The average TDS of boreholes in the VDWHS was $250 \mathrm{mg} / \mathrm{L}, \mathrm{pH}$ neutral at 7.1 and chloride at $25 \mathrm{mg} / \mathrm{L}$, which is acceptable.

\subsection{Water Chemistry}

The chemical analyses of 138 groundwater samples were used to determine the chemical characteristics of groundwater in the VDWHS. From this data, a piper diagram was plotted and is presented in Figure 10. This methodology represents a ternary plot which can be used as an indicator towards the definition of the source of the groundwater and sample age and origin relative to each other [7].

From the chemical analyses presented in the piper diagram, the following aspects became evident:

- The water types are dominated by calcium-magnesium-carbonate and the character of the water is very similar for all of the 138 samples analyzed.

- There is a high proportion of carbonate water with dominant $\mathrm{HCO}_{3}$ anion present. The cation domination is reflected on the left triangle of the diagram and indicates a domination of calcium and magnesium.

- The majority of the water sources appear to be recent. This means that there is a short delay or lag time between recharge and entry into the capture zone of the boreholes. The implication is that the water in the aquifers is not held in storage for very long and that the water is largely rainfall derived as opposed to seepage from surface water sources and deep aquifer circulation. 
Figure 10. Piper Diagram: Chemical analyses of 138 samples within the VDWHS.

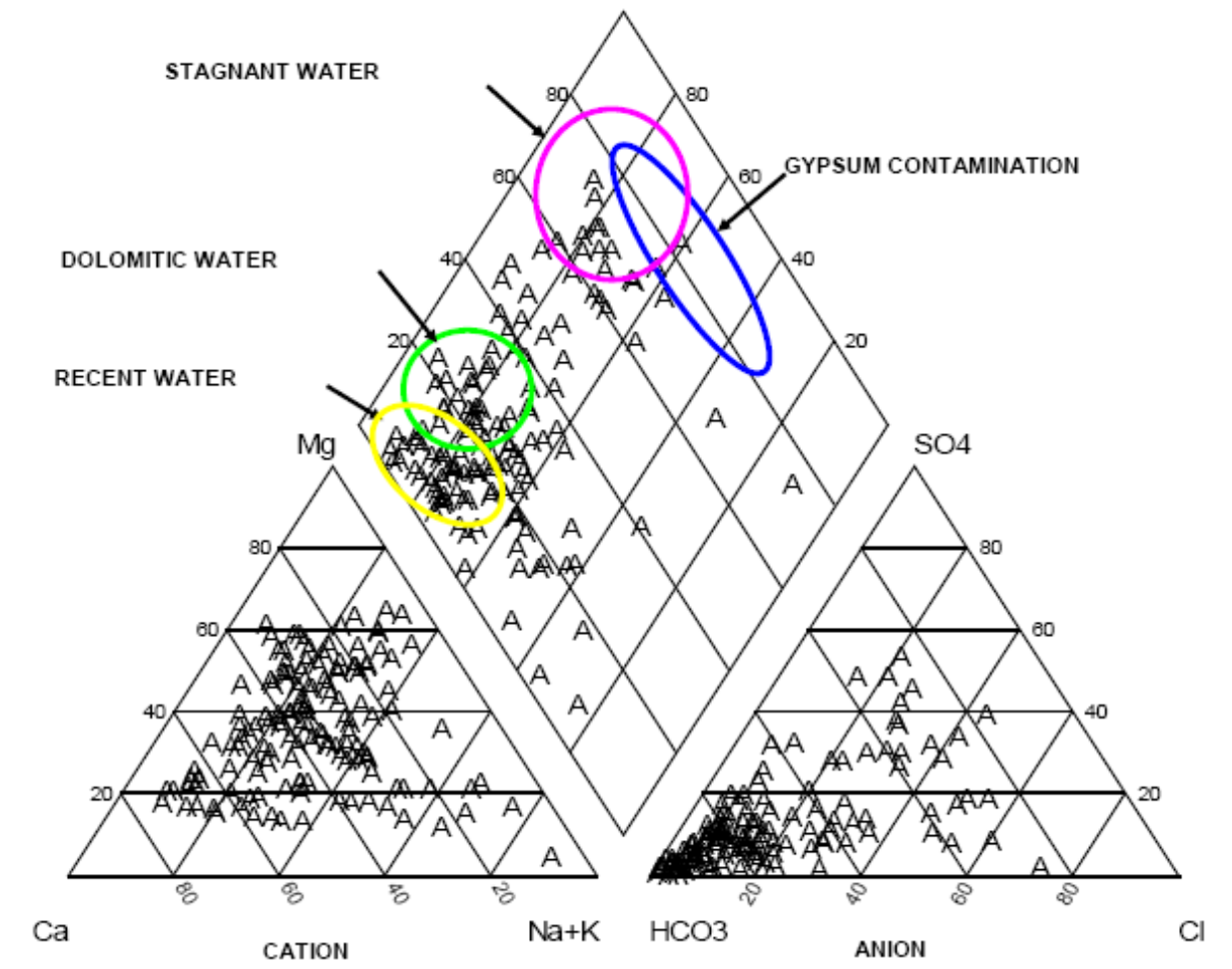

\subsection{Groundwater Recharge}

Recharge was calculated by the application of the chloride methodology and verified by the estimations according to general guidelines and available information [26]. The chloride concentration are summarized in Table 2.

Table 2. Chloride concentration statistics in samples from the VDWHS

\begin{tabular}{|c|c|c|}
\hline & mg/L & Recharge \% \\
\hline Maximum & 434 & 0.2 \\
\hline Minimum & 0.71 & 140 \\
\hline Average & 24.87 & 4 \\
\hline Standard deviation & 48.4 & 2 \\
\hline
\end{tabular}

The average of the chloride concentrations recorded for the samples taken at 138 boreholes, was calculated as $24.87 \mathrm{mg} / \mathrm{L}$. A chloride concentration of $1 \mathrm{mg} / \mathrm{L}$ was assumed for rainwater. In Table, the chloride concentration in rainwater is divided by the concentration measured in boreholes. This gives a range from $0.2 \%$ to $140 \%$ recharge, the latter being an anomaly which has been influenced by additional chloride sources (e.g., waste, sanitation, etc.) and is disregarded. Using the average of the chloride concentrations, a recharge of approximately $4 \%$ of MAP has been calculated with a standard deviation of $2 \%$.

To verify the accuracy of this calculation, the following information regarding recharge was used:

- The Groundwater Harvest Potential Maps of South Africa [33] indicated variability in recharge as one of the factors restricting the groundwater harvest potential.

- According to the geological and lithological character of the VDWHS, recharge may differ 
from $4 \%$ (granites) to $6 \%$ (dolomites) throughout the study area, with an estimated recharge of $7 \%$ in areas underlain by shale/quartzite successions [26].

- The recharge calculations for the Catchments $\mathrm{C} 23 \mathrm{C}$ and $\mathrm{C} 23 \mathrm{~L}$ are given as $6.5 \%$ and $6.2 \%$, respectively [26].

- According to national compilations the VDWHS falls within a recharge zone of $25-35 \mathrm{~mm} / \mathrm{a}$ [26].

Based on the chloride method and verification above, the recharge rate for calculation of the water balance was assumed to be $6 \%$. It is however important to note that further research is needed to verify this figure.

\subsection{Groundwater Balance}

A conceptual water balance was developed for the core zone of the VDWHS as an indicator of availability of groundwater for future development and groundwater management in the Dome area. It should be noted that these volumes are estimations and further detailed information is required for more accurate figures for individual groundwater management units before the "safe yield" can be calculated [38].

The conceptual water balance is based on the following:

- Recharge: The total surface of the core area of the VDWHS is $280 \mathrm{~km}^{2}$. An annual rainfall estimation of $609 \mathrm{~mm} / \mathrm{a}$ was obtained from the reserve determination tool as developed by the DWAF [25]. With an average recharge of in the order of $6 \%$, a recharge volume in the order of $10,231 \times 10^{6} \mathrm{~m}^{3} / \mathrm{a}$ was calculated.

- Existing groundwater abstraction rates: The borehole survey was used to calculate the existing groundwater abstraction rates to a total of $4.352 \times 10^{6} \mathrm{~m}^{3} / \mathrm{a}$ (Table 3 ).

Table 3. Current abstraction and spring flow calculations.

\begin{tabular}{|c|c|c|c|c|}
\hline Equipment & Number & $\begin{array}{c}\text { Estimate } \\
\text { abstraction }(\mathrm{L} / \mathrm{S})\end{array}$ & $\begin{array}{c}\text { Pumping } \\
\text { (hours/day) }\end{array}$ & Volume ( $\mathrm{m}^{3} /$ day) \\
\hline Wind pumps & 54 & 0.8 & 16 & 2.5 \\
\hline Mono type pumps & 25 & 2 & 12 & 2.1 \\
\hline $\begin{array}{c}\text { Submersible } \\
\text { pumps }\end{array}$ & 186 & 1 & 12 & 8.0 \\
\hline Springs & 19 & 1 & 24 & 1.6 \\
\hline \multicolumn{4}{|c|}{ Estimated total ( $\mathrm{m}^{3}$ per day) } & 14,325 \\
\hline \multicolumn{4}{|c|}{ Estimated total ( $\mathrm{m}^{3}$ per annum) } & $5,228,669$ \\
\hline
\end{tabular}

- Base flow component: Based on maps by Vegter [11], and a reserve determination methodology developed by the DWAF [25], a base flow component of $4 \mathrm{~mm} / \mathrm{a}$ is required for the catchments. For the total area of $280 \mathrm{~km}^{2}$, calculated per day, this yields a volume in the order of $1.120 \times 10^{6} \mathrm{~m}^{3} / \mathrm{a}$ - see Table 4 .

- Basic human need: The official reserve determination is at this stage still outstanding and will play a critical role in the water balance calculation for the VDWHS and is therefore needed prior to any future development in the area. Currently, basic human needs are set by the Water Service Act (Act 108/1997) [39] at 25 liters per person per day (1/p/d). According to the 
borehole survey results in the order of 150 farming units exist in the core area, which correlate with the a total of 148 farms recorded [40]. For the present calculation the basic human need component of the reserve was estimated as $136 \mathrm{~m}^{3} /$ day based on the number of farms in the study area. The Basic Human Need Calculation is shown in Table 5.

Table 4. Required base flow calculation for VDWHS.

\begin{tabular}{|c|c|c|}
\hline Surface area $\left(\mathbf{m}^{\mathbf{2}}\right)$ & Minimum base flow (m) & Annual volume: base flow $\left.\mathbf{( m}^{\mathbf{3}}\right)$ \\
\hline $280,000,000$ & 0.004 & $1,120,000$ \\
\hline
\end{tabular}

Table 5. Basic Human Need Calculation.

\begin{tabular}{|c|c|}
\hline Number of farms & 150 \\
\hline Estimated number of people per farm & 8 \\
\hline Total number of people & 1,200 \\
\hline Reserve (liter per person per day) & 25 \\
\hline Total annual basic need $\left(\mathrm{m}^{3}\right)$ & 10,950 \\
\hline
\end{tabular}

Based on all this information and calculations, the conceptual groundwater balance for the VDWHS is summarized and calculated in Table 6. As calculated in this table, it is evident that the groundwater balance is still positive, but under stress (approximately $7 \%$ of the available total inflow of water).

Table 6. Conceptual groundwater balance.

\begin{tabular}{|c|c|c|}
\hline Component & Inflow $\left(\mathbf{m}^{\mathbf{3}} / \mathbf{a}\right)$ & Outflow $\left.\mathbf{~ m}^{\mathbf{3}} / \mathbf{a}\right)$ \\
\hline Recharge & $6,820,800$ & $1,120,000$ \\
\hline Base flow & & $5,228,669$ \\
\hline Estimated current abstraction & & 10,950 \\
\hline Basic human need & & $6,359,619$ \\
\hline Total & $6,820,800$ & \\
\hline Balance $\left(\mathrm{m}^{3}\right)$ & 461,181 & \\
\hline Balance $(\%)$ & $7 \%$ & \\
\hline
\end{tabular}

\section{Discussion}

\subsection{Description of the Different Groundwater Resource Management Units}

Based on the surveyed data as well as calculations shown in the previous sections, groundwater management units have been identified and delineated, as shown in Figure 11. The Aquifer Vulnerability Classification methodology [41] was applied in the risk assessment of the groundwater.

A brief description of the attributes of each management unit, as well as strategic prerequisites for sustainable management, is provided in the following section. 
Figure 11. Goundwater resource management units in the VDWHS.
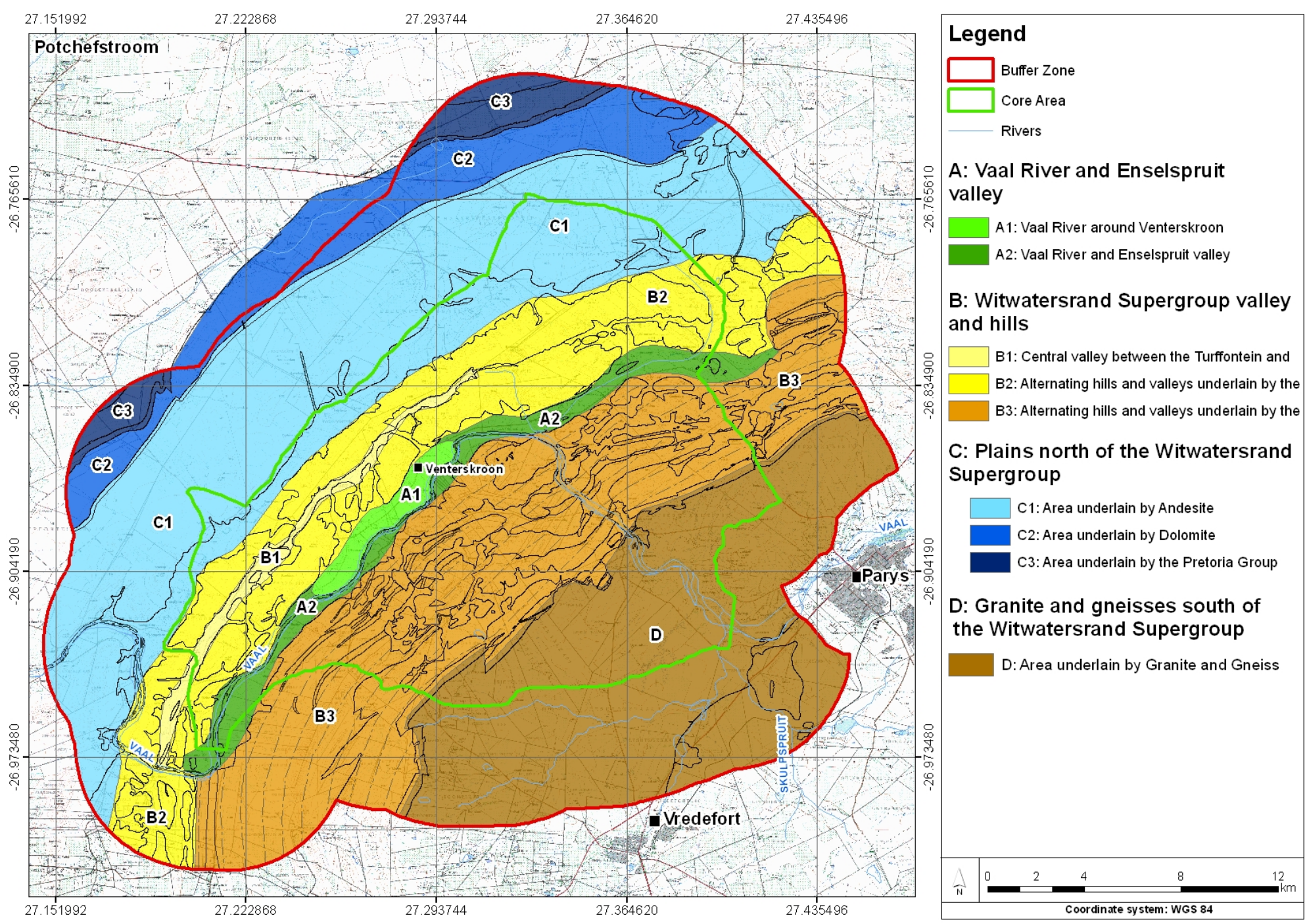


\subsubsection{Groundwater Resource Management Unit A: Vaal River and Enselspruit Valley}

- Unit A1 comprises the area next to the Vaal River around the hamlet of Venterskroon. It consists of hills and outcrops surrounding a weathered valley area underlain by sand, soil, gravel, ferricrete, alluvial and weathered formations associated with the Vaal River drainage system. A total of 16 water samples from boreholes were analyzed, and water quality is generally good with the exception of two boreholes. The depth to the water table is 13-17 meters. Based on the fact that a state owned property which will be developed as an information center falls within this area, this area is likely to become the hub of future tourism activities. Due to the higher local permeability and transmissivity of the aquifer, potential development in the Venterskroon area may have a negative impact on the water quality. Special care should therefore be taken in the design and maintenance of sanitation systems at existing as well as new developments within the area. The approval of any individual land use change and related water rights must be based on a geohydrological impact assessment of Unit A1 as a whole. Such a study should include a detailed geohydrological status assessment, aquifer character investigation, experimental source development, modeling and risk analyses as well as a groundwater management plan.

- Unit A2 is the remainder of the Enselspruit and part of the Vaal River drainage system. It is underlain by sand, gravel, ferricretes, alluvium and weathered formations with a high permeability and transmissivity. A high density of development and tourism activity occurs along the river in this unit and it results in the lowest groundwater quality of all units in the VDWHS. Due to the high hydraulic conductivity, local contamination such as a leaking sewerage system may have a regional effect. The cumulative effect of all impacts has caused the low water quality in the area. Forty-five percent of the boreholes in this unit have elevated levels of $\mathrm{N}, \mathrm{Ca}, \mathrm{Mg}, \mathrm{SO}_{4}, \mathrm{Cl}, \mathrm{HCO}_{3}, \mathrm{EC}$ and TDS. A regional geohydrological study for any proposed development is therefore recommended for this unit (similar to Unit 1). Such studies should include strategies and methodologies to improve poor quality groundwater.

\subsubsection{Groundwater Resource Management Unit B: Witwatersrand Supergroup Valleys and Hills}

- Unit B1 comprises the central valley developed between the Turffontein Subgroup to the north and Johannesburg Subgroup to the south. This valley runs partially parallel with the Vaal River Valley (unit A1) and is the result of erosionally resistant quartzite horizons with shale found in the valleys [27]. A detailed delineation of the area indicates an interdependence with the linear aquifers developed in the adjacent quartziterich hills [27]. Groundwater levels in this valley are low, indicating that the aquifer is under stress. Hence, a detailed regional geohydrological assessment is needed for this unit prior to any further groundwater use.

- Unit B2 includes the rest of the alternating hills and valleys underlain by the Central Rand Group as a generalized combination of smaller locally developed aquifer systems with variations in character. This unit is underlain by variable geological formations of quartzites, shales, sedimentary successions and localized weathered zones stretching in a general northeasterly, southwesterly direction. Water levels and water quality differ from point to point 
throughout unit B2 due to the complex geological structure and character of the area. Thus, a regional geohydrological assessment of this area will be of a generalized nature and not of practical value from a management point of view. It is therefore recommended that any local land use application and related water right must be supported by a site specific geohydrological assessment to determine the parameters of each specific case.

- Unit B3 is underlain by the Jeppestown, Government and Hospital Hill Subgroups as part of the West Rand Group representing different locally developed aquifer systems. Rocks include undifferentiated successions of quartzite, sandstone, slate conglomerate, hornfels with politic beds stretching in a general northeasterly, southwesterly direction. As in Unit B2, water levels and water quality vary due to the complex geological structure and character of the area, and therefore site specific geohydrological impact assessments should be required for any land-use change applications.

\subsubsection{Groundwater Resource Management Unit C: Plains North of the Witwatersrand Supergroup}

- $\mathrm{C} 1$ is situated in the north and northwestern areas of the VDWHS underlain by andesite of the Klipriviersberg Group, Ventersdorp Supergroup. Water quality is generally good, especially in the area overlain with alluvium directly north of the Witwatersrand Supergroup, with the exception of a single borehole showing an elevated concentration of Fe. Nitrate $\left(\mathrm{NO}_{3}\right)$, bicarbonate $\left(\mathrm{HCO}_{3}\right), \mathrm{NH}_{3}, \mathrm{EC}$ and TDS levels are low, indicating that this area is not sensitive to development activities. The water table in this unit is the deepest in the VDWHS, making it less vulnerable to pollution from land use activities.

- Unit C2 is underlain by Malmani dolomites to the north and northwest of the andesites. Because not much future development is expected in this unit, there is a reduced risk of groundwater contamination. However, this unit is of great importance to the VDWHS due to high yielding boreholes and good water quality. Land use applications in this unit are therefore regarded as a sensitive issue since development on dolomites increase the risk of sinkholes and interrupted natural surface drainage [42]. Ongoing monitoring and maintenance of water bearing services, as well as the implementation of precautionary measures relating to drainage and infiltration of surface water, are regarded as essential for developing any infrastructure on dolomites [43]. Due to the interaction between groundwater and stability in karstic areas, the assessment, planning and management of groundwater should be done in strict accordance with the guidelines from DWAF [26].

- Unit C3 comprises a small portion of the area underlain by rocks of the Pretoria Group. Rocks include quartzites, shale and andesite with a low groundwater potential, and no specific management measures are proposed.

4.1.4. Groundwater resource management Unit D: Granite and gneiss plains south of the Witwatersrand Supergroup

- Unit D represents the area south of the Witwatersrand Supergroup and forms the southern part of the VDWHS. The water table is very shallow resulting in the aquifer being vulnerable to pollution from surface activities. Land-use practices in this unit must take note of the 
vulnerability of the aquifer and special care must be taken to ensure appropriate sanitation and waste management practices.

\section{Strategic Management Objectives}

\subsection{Water Balance}

In light of the critical point of balance in groundwater inflow and outflow in the VDWHS, any new groundwater demands will pose a threat to the availability of groundwater. Table 7 summarizes the water supply requirements related to expected new developments. The water demand of new developments therefore has to be calculated as part of the application process to determine what the impact will be on the existing groundwater balance. The aquifer water balance should always be positive and water abstraction allocation should be denied if it would cause the water balance within the aquifer to become negative.

Abstraction protection zones are defined by the radius of influence (ROI) of specific abstractions from the same aquifer. The proximity of production boreholes to one another has a cumulative effect on the water levels [44]. Any applications to abstract ground water should therefore quantify the ROI in aquifer units. The greater aquifer protection zone in terms of abstraction also applies to wellfield development as the cumulative impact of a wellfield is likely to be represented over a greater area than the impact of a single borehole. Constant rate pump tests should be performed to determine the sustainable yield for individual boreholes according to South African National Standards [45]. If groundwater levels decline by more than $80 \%$ of the depth of the borehole during production, it is rendered an unsustainable yield and alternative sources should be secured or the pump rate should be adjusted.

Table 7. VDWHS Water supply and demand estimates.

\begin{tabular}{|c|c|c|}
\hline \multicolumn{2}{|c|}{ Land use or utilization category } & Figure for estimated demand \\
\hline \multicolumn{2}{|c|}{ 1 Development demand } \\
\hline Description of water supply & $\begin{array}{c}\text { Consumption } \\
\text { Liter /person/day }\end{array}$ & $\begin{array}{c}\text { Consumption } \\
\text { Liter/hectare/day }\end{array}$ \\
$\Rightarrow$ Dwelling houses & 245 & \\
$\Rightarrow$ Laborers' houses & 150 & \\
$\Rightarrow$ Guest houses & 280 & \\
$\Rightarrow$ Conference facilities & 70 & \\
$\Rightarrow$ Resorts & 215 & 3,000 (Summer) \\
$\Rightarrow$ Business and commercial & 183 & 1,850 (winter) \\
$\Rightarrow$ Education facilities/ team building & 31 & \\
$\Rightarrow$ Offices & 56 & \\
$\Rightarrow$ Gardening and landscaping & 35 (2 X per week) & \\
$\Rightarrow$ Churches & 105 & \\
$\Rightarrow$ Other buildings & 80 & \\
$\Rightarrow$ Tourist (Day visitors) & & \\
\hline
\end{tabular}


Table 7. Cont.

\begin{tabular}{|c|c|c|}
\hline \multicolumn{2}{|c|}{ Land use or utilization category } & Figure for estimated demand \\
\hline \multicolumn{2}{|c|}{ 2 Agricultural demand } \\
\hline Description of water supply & \\
$\Rightarrow$ Surface irrigation (crops) & 500 to 1,000 \\
$\Rightarrow$ Sub-surface irrigation (crops) & 250 to 275 \\
$\Rightarrow$ Average agricultural demand & & 80 to 150 \\
$\Rightarrow$ Horticulture & 3,000 to 3,500 \\
$\Rightarrow$ Cattle farming & \\
$\Rightarrow$ Poultry & 25 to 35 & \\
$\Rightarrow$ Small animal farming & 25 to 25 & \\
$\Rightarrow$ Game farming & 20 to 25 & \\
$\Rightarrow$ Other agriculture-related demand & 15 to 20 & \\
\end{tabular}

Groundwater exploitation

\subsection{Recharge Reduction}

Specific land uses may influence the natural state of vegetation, topography and soil properties that may lead to reduction in recharge to groundwater [26]. These activities include the development of storm water drainage systems, ploughing of lands and the development of certain types of crops [5].

\subsection{Sanitation}

The protection of boreholes from seepage from soakaways and septic tanks requires a buffer zone to be created down-gradient from the location of the sewage system. The travel of bacteria from the sewage into the borehole capture zone under the influence of abstraction should not be underestimated. Ideally, all sewage should be disposed of into septic tanks that are emptied on a regular basis. It is recommended to apply the decision support framework and impact methodology as developed by Vivier [46] to identify the appropriate sanitation technology on a regional scale in future developments.

\subsection{Surface Disposal of Waste}

The disposal of domestic and agricultural solid waste has been determined to be a potentially problematic issue since the potential impact on the groundwater is related to the quality of the seepage from such disposal, be it temporary or long-term. Disposal of any waste should only be licensed after an impact assessment has been done.

\subsection{Vaal River Ingress}

Water levels in boreholes near the Vaal River are higher than the level of the Vaal River itself so that ingress from the Vaal River to the boreholes does not occur at this point in time. However, any lowering in water levels in the boreholes to below the piezometric head of the Vaal River could pose a problem. The groundwater levels in these regions therefore need to be continually monitored. In line 
with the precautionary principle, it is advised that no abstraction boreholes should be developed within $100 \mathrm{~m}$ of the Vaal River.

\subsection{Sinkholes}

Dolomite covers only a small elongated zone on the northwestern side of the VDWHS. Sinkholes could result from over abstraction of groundwater resources, uncontrolled storm water drainage and leakages from water pipes and sanitation facilities. Specialist geotechnical investigations are carried out as standard practice prior to the development of buildings on dolomite in order to quantify the potential risk of sinkholes. Additional groundwater management measures are required in the dolomite if wellfields are to be developed, to ensure that there is no additional risk of sinkhole formation as a result of abstraction.

\subsection{Storm Water Management}

The protection of the aquifers from seepage of lesser quality surface water from storm water run-off should be prevented by having a compulsory storm water management plan for all developments, for example petrol stations and lodges.

\subsection{Alien Vegetation}

Alien vegetation such as the sp. Acacia Karoo and sp. Eucalyptus have the potential to reduce recharge [47] and should be eradicated.

\subsection{Application of Fertilizer}

The application of fertilizer has the potential to increase the salt load and specifically the nitrate concentration of water. Land use activities involving the application of fertilizer should therefore introduce a groundwater monitoring plan to ensure that groundwater quality is not compromised.

\subsection{Institutional Framework}

Although the Environmental Impact Assessment is one of the most important conservation tools in South Africa [48], it is not an explicit requirement of the EIA procedure that a geohydrological assessment should be done as part of any land use change application. It is proposed that the regulations regarding the licensing of water uses related to land use activities as defined in the National Water Act (36/1998) [49] be incorporated in regulations and procedures related to land use management and spatial planning in a much more direct manner, and that it be made a requirement of the EIA process. The suggested layout and structure of the proposed amended procedure is shown in Figure 12, where the blue blocks indicate proposed amendments. 
Figure 12. Integration of geohydrological and land use processes: structure of procedures and actions.

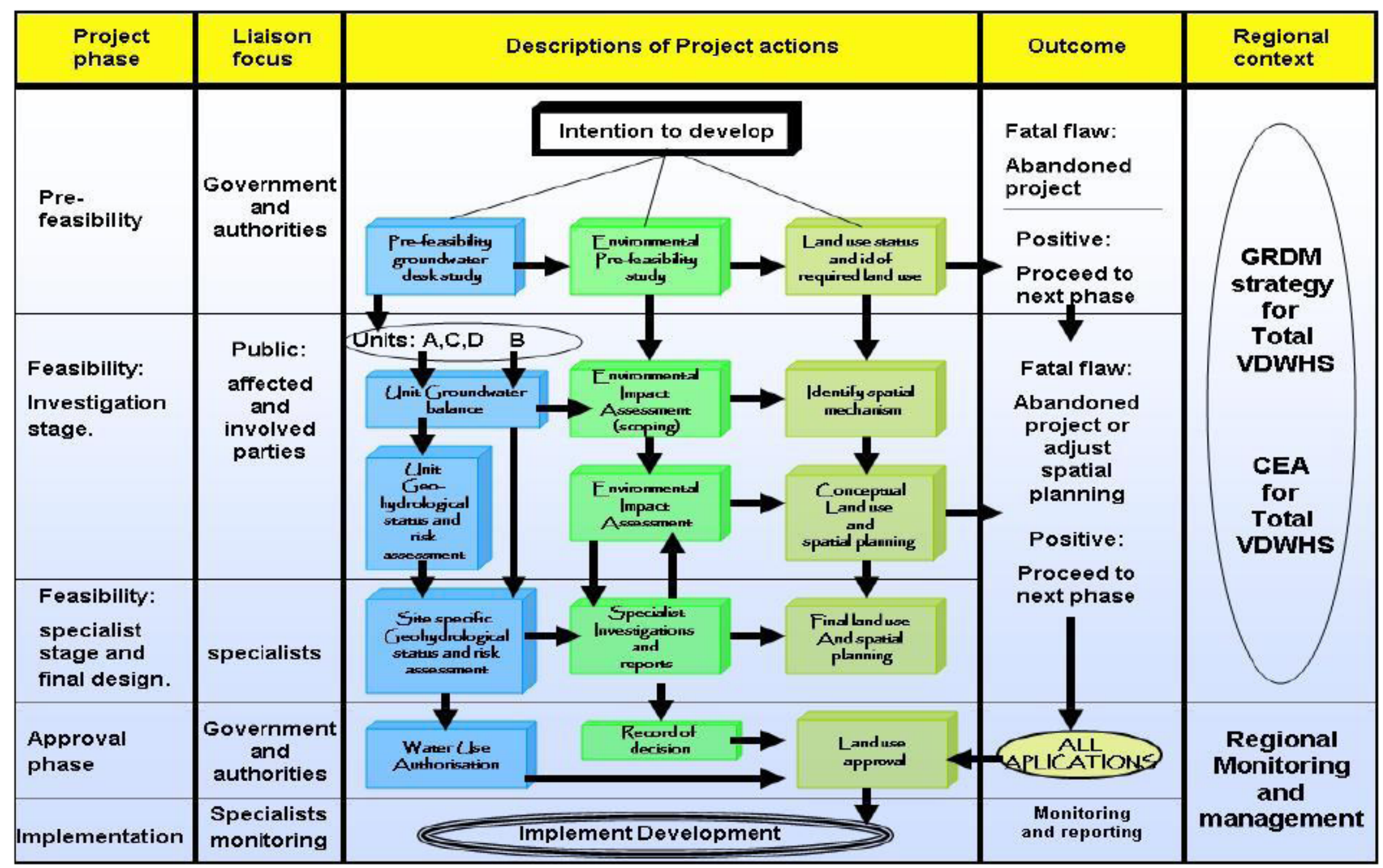




\section{Conclusions}

It is evident that the availability of groundwater for water supply to development is the single determining factor for sustainable land use management and spatial planning in the VDWHS. The authorization of any new land use and related development should be dependent on the safe yield of the aquifers in the VDWHS, regardless of all other factors. Only if the current institutional framework in South Africa is amended to ensure adequate consideration is given to the groundwater in all land use applications in the VDWHS, will sustainability be achieved.

\section{Acknowledgements}

The research was funded by the Free State Department of Tourism, Environmental and Economic Affairs, South Africa

\section{References}

1. IUCN. Vredefort Dome South Africa; World Heritage Evaluation Report. Available online: http://www.unep-wcmc.org/sites/wh/pdf/Vredefort\%20dome.pdf 2004 (accessed on 12 September 2008).

2. Puren, K.; Drewes, E.; Roos. V. An exploration of sense of place as informative for spatial planning guidelines: A case study of the Vredefort Dome world heritage site, South Africa. Int. J. Soc. Sci .2007, 1, 190-197.

3. AFRICAN EPA. Vredefort Dome Strategic Environmental Assessment. Internal Report Rendered to the Northwest Department of Agriculture and Tourism; Prepared by Consortium of Consultants under leadership of African EPA: Pretoria, South Africa, 2006.

4. Van Tonder, G.; Dennis, I.; Vermeulen, D. The Importance of Constructing a Correct Conceptual Model for an Aquifer. In Proceedings of Water Resources of Arid Areas-Stephenson, Shemang \& Chaoka; Taylor \& Francis Group: London, UK, 2004.

5. Scanlon, B.R.; Keese, K.E.; Flint, A.L.; Frint, L.E.; Gaye, C.G.; Edmunds, W.M.; Simmers, I. Global Synthesis of Groundwater Recharge in Semi-Arid and Arid Regions; Wiley: Hoboken, NJ, USA, 2006; Available online: www.interscience.wiley.com. (accessed on 12 September 2008).

6. Smit, J.J.; Pretorius, S.J. Geohydrological Assessment for the evaluation of groundwater for a proposed development on potion 5 of the farm Prinsloosrust 489 IQ in the Potchefstroom area, North West Province; Report 2008-02-05-GWSEAGES, Potchefstroom, South Africa, 2008.

7. Braune, E. Towards a New Phase of Groundwater Reserve Assessment; Unedited working paper; Directorate Geohydrology Workshop: Pretoria, South Africa, 3 November 2000.

8. Saayman, I. Guideline for Involving Hydro-Geologists in EIA Processes, 1st ed; CSIR Report No ENV-S-C 2005053 D; Provincial Government of the Western Cape, Department of Environmental Affairs and Development Planning: Cape Town, South Africa, 2005.

9. Pearson, L.A.; Bhagwan, J.; Kariuki, W.; Banda, W. Guidelines on Appropriate Technologies for Water Supply and Sanitation in Developing Communities; WRC: Pretoria, South Africa, 2002.

10. Botha, F.S.B. A Proposed Method to Implement a Groundwater Resource Information Project (GRIP) In Rural Communities, South Africa. Ph.D. Thesis, University of the Free State, 
Bloemfontein, South Africa, 2005.

11. Vegter, J.R. Groundwater Development in South Africa and Introduction to the Hydrogeology of the Groundwater Regions; Water Research Commission: Pretoria, South Africa, 2001.

12. Haupt, C.J. Explanation Sheet of the 1:500 000 Hydro Geological Map 2326 Pietersburg; WRC: Pretoria, South Africa, 2005.

13. Baron, J.; Seward, P.; Seymour, A. The Groundwater Harvest Potential Map of The Republic of South Africa; DWAF: Pretoria, South Africa, 1996.

14. Du Toit, W.H. Geohidrologie van die Nasionale Krugerwildtuin gebaseer op die evaluering van bestaande boorgat inligting; DWAF: Geohydrology, Pretoria, 1998; volume 1 and 2.

15. Barnard, H.C. An Explanation of the 1:500 000 General Geohydrological Map, Johannesburg 2526; DWAF: Pretoria, South Africa, 2000.

16. Vivier, J.C. Development of an Impact Assessment Methodology and Decision Making Tool to Assist in the Evaluation of Site Suitability for On-site Sanitation Sytems. Ph.D. Thesis, Potchefstroom Campus of the North West University, South Africa, 2006.

17. Parsons, R.; Wentzel, J. Setting Resource Directed Measures (RDM) for Groundwater: A Pilot Study; WRC: Pretoria, South Africa, 2007.

18. De, W.; Raath, C.J. Geohydrological Investigation of the Water Supply to the Proposed Zandrivierspoort Mine from Groundwater Sources; AGES: Potchefstroom, South Africa, 2008.

19. Brink, M.C.; Bisschoff, A.A.; Waanders, F.B.; Schoch, A.E. The Vredefort Astrobleme and Similar Terrestrial Structures: A Comparative Analysis; North West University and University of the Free State: Bloemfontein, South Africa, 2005. (Addendum to the supplementary Information to the Vredefort Dome nomination dosser to UNESCO).

20. Bisschoff, A.A. The Geology of the Vredefort Dome. Explanation of geological sheets 2627CA, $C B, C C, C D, D A, D C$, and 2727AA, AB, BA (1:50 000); Council for Geoscience, Geological Survey of South Africa: Pretoria, South Africa, 1999.

21. Brink, M.C.; Bisschoff, A.A.; Waanders, F.B.; Schoch, A.E. The Geology of the Impact Structure around Vredefort; Department of Tourism, Environmental and Economic Affairs, Free State Province: Bloemfontein, South Africa, 2004. (Included as supplementary Information to the Vredefort Dome nomination dossier to UNESCO).

22. Reimold, W.U.; Gibson, R.L. Meteorite Impact!: The Danger from Space and South Africa's Mega-impact: The Vredefort Structure; Springer-Verlag: Heidelberg, Germany, 2010.

23. Reimold, W.U.; Coney, L. The Vredefort Impact Structure and Directly Related Subjects: An Updated Bibliography; Economic geology research institute, University of the Witwatersrand: Johannesburg, South Africa, 2001.

24. Lattman, L.H.; Ray, R.G. Aerial Photographs in Field Geology; Holt, Rinehart and Winston: New York, NY, USA, 1965.

25. GRDM. Groundwater Resource Directed Measures: Version 2.5. Institute for Groundwater Studies, University of the Free State, Bloemfontein, South Africa; Department of Water Affairs and Forestry, Pretoria, South Africa, 2008.

26. Groundwater Reserve Assessment II-task 3aE Recharge. Tender 2003-150 Final Report; Department of Water Affairs and Forestry: Pretoria, South Africa, 2006. 
27. Brink M.C.; Waanders, F.B.; Bisschoff, A.A. The potential effect of prospecting or mining on the Vredefort Dome World Heritage Site. In Proceedings of the 2nd International Conference of Chemistry and the Environment; School of Chemical and Minerals Engineering, North-West University: Potchefstroom, South Africa, 2005; pp. 274-278.

28. Parsons, R. A South African Aquifer System Management Classification; Water Research Commission: Pretoria, South Africa, 1995.

29. Vegter, J.R. Groundwater Resources of the Republic of South Africa; WRC: Pretoria, South Africa, 1995.

30. Desbarats, A.J.; Logan, C.E.; Hinton, M.J.; Sharpe, D.R. On the Kriging of water table elevations using collateral information from a digital elevation model. J. Hydrol. 2002, 255, 1-4.

31. Golden Software, 2002 Golden Software, Surfer 8. Contouring and 3D Surface Mapping for Scientists and Engineers. User's guide; Golden Software, Inc.: Golden, CO, USA, 2002; pp. 640.

32. Quality of Domestic Water Supplies. Volume 2: Sampling guide; Department of Water Affairs and Forestry, Water Research Commission: Pretoria, South Africa, $2003 \mathrm{~b}$.

33. Department of Water Affairs and Forestry. South African Water Quality Guidelines. Volume 1: Domestic, 2nd ed.; Department of Water Affairs and Forestry: Pretoria, South Africa, 1996.

34. Quality of Domestic Water Supplies. DWAF and Water Research Commission, Volume 1: Assessment Guide, 2nd ed.; Department of Water Affairs and Forestry. Pretoria, South Africa, 1998.

35. South African National Standards. Addition 6.1. South African National Standards 241: Drinking Water Standards; South African Bureau of Standards: Pretoria, South Africa, 2006.

36. South African Water Quality Guidelines. Volume 4: Agricultural Water Use-Irrigation. Volume 5: Agricultural Water Use-Livestock Watering, 2nd ed.; Department of Water Affairs and Forestry: Pretoria, South Africa, 1996.

37. Apello, C.A.J.; Postma, D. Geochemistry, Groundwater and Pollution; CRC: Pretoria, South Africa, 2005.

38. Seward, P.; Xu, Y.; Brendonck, L. Sustainable groundwater use, the capture principle, and adaptive management. Water SA 2006, 32, 473-481.

39. South Africa. Water Services Act no. 108 of 1997; Government Gazette 3901997.

40. Du Pisani, J.A. Cultural Heritage Plan. In AGES, 2007 Vredefort Dome World Heritage Site: Integrated Management Plan. Internal Final Draft report no. 31-3-2007; Department of Tourism Environment and Economic Affairs, Free State Province: Bloemfontein, South Africa. 2005.

41. Groundwater Protocol. Summary Version. Protocol for the Protection of Groundwater from Contamination from Sanitation Practices, Version 2; Department of Water Affairs and Forestry: Pretoria, South Africa, 2003a.

42. Pretorius, S.J.; Hattingh, A.M. Geo-Environmental Assessment of Mining Related Urban Development. In Planning and Development perspectives for Mining Towns in South Africa Conference; Northwest University: Potchefstroom, South Africa, 2008.

43. De Bruyn, I.A.; Bell, F.G. The occurrence of sinkholes and subsidence depressions in the far west Rand and Gauteng Province, South Africa, and their engineering implications. Environ. Eng. Geosci. 2001, 7, 281-295. 
44. Heath, R.C. Basic Ground-Water Hydrology: U.S. Geological Survey Water-Supply Paper 2220; Open File Service Section: Denver, CO, USA, 2004.

45. Development, Maintenance and Management of Groundwater Resources; South African National Standards: Pretoria, South Africa, 2002; Parts 1-2, 4-9.

46. Wright, K.A.; Xu, Y. A water balance approach to the sustainable management of groundwater in South Africa. Water SA 2000 26, 167-170.

47. Le Maitre, D.C.; Scott, D.F.; Colvin, C. A review of information on interaction between vegetation and groundwater. Water SA 1999, 25, 137-152.

48. Kidd, M. EIA's and the four P's: Some observations in South Africa. In Land Use Law for Sustainable Development; Cambridge University: New York, NY, USA, 2007.

49. South Africa. National Water Act, Act no. 36 of 1998; Government Gazette 398, 1998.

(C) 2010 by the authors; licensee MDPI, Basel, Switzerland. This article is an open access article distributed under the terms and conditions of the Creative Commons Attribution license (http://creativecommons.org/licenses/by/3.0/). 